фізика: das Geräuschspektrum (акустичний спектр) [5, с. 234];

метеорологія: die Jahresniederschläge (річна кількість опадів) [5, с. 345]; географія: die Wirtschaftslandschaft (техногенний ландшафт) [5, с. 728];

океанологія: die Verschmutzung der Meere (забруднення світового океану) [5, с. 734];

хімія: die Schadstoffgrenze (порогова маса небезпечних речовин) [5, с. 672];

радіологія: die Interventionsschwelle (поріг втручання) [5, с. 385];

медицина: die Schmerzschwelle (поріг больового відчуття) [5, с. 675];

правознавство: die Gifffreisetzung (викид токсичних речовин у навколишнє середовище (вид екологічного злочину) [5, c. 231].

Межа між терміносистемами екології та інших природничих наук $\epsilon$ нечіткою, розмитою, оскільки спостерігається міграція термінів.

\title{
Література:
}

1. Бондар О., Козловська Л. Семантико-граматичні типи терміносполук у галузі екології. Українська термінологія і сучасність: зб. наук. праць. К., 2003. Вип. V. С. 134-139.

2. Мусієнко М. М., Серебряков В. В., Брайон О. В. Екологія. Охорона природи: словник-довідник. К. : Знання, 2002. 550 с.

3. Овсейчик С. В. Формування української екологічної термінології: дис. ... канд. філол наук: 10.02.01. К., 2006. 199 с.

4. Панько Т. І., Кочан І. М., Мацюк Г. П. Українське термінознавство. Львів: Світ, 1994. 216 с.

5. Новиков Ю. Н. Немецко-русско-немецкий словарь по экологии и защите окружающей среды. М. : ЭТС Polyglossum, 2004. 980 c.

DOI https://doi.org/10.30525/978-9934-588-90-7-29

\section{СПЕЦИФІКА РЕЛІГІЙНОГО ДИСКУРСУ}

\author{
Бондаренко К. А. \\ кандидат філологічних наук,
}

доцент кафедри теоретичної та прикладної фонетики англійської мови

Одеський начіональний університет імені I. I. Мечникова

м. Одеса, Україна

Наукове вивчення релігійного дискурсу, активізоване останнім часом на пострадянському просторі, становить не лише особливий інтерес, а й певні труднощі. Будучи за формальними ознаками інституційним 108 
спілкуванням, релігійний дискурс за суттю є дискурсом віри, «яка домінує над раціональним знанням i водночас припускає знанняодкровення» [6, с. 6]. Специфіка релігійного дискурсу лише 3 певною часткою умовності дає змогу уналежнити його до власне інституційного спілкування.

С. В. Блувберг так характеризує його сутність: «Під релігійним дискурсом розуміється особливий тип інституційного дискурсу, спеціалізований клішований різновид спілкування, зумовлений соціальними функціями партнерів і регламентований як за змістом, так i за формою, механізм фіксації священного, сакрального знання, створення на його основі певної моделі поведінки з метою залучення до віри в рамках певної конфесії, за допомогою якої оцінюється поведінка конкретних людей [1, с. 14].

Є.О.Кожем'якін, розуміючи під релігійним дискурсом «регламентовану певними історичними та соціокультурними кодами (традиціями) смислоутворювальну і смисловідтворювальну діяльність, спрямовану на формування, трансляцію і зміну догматичного мислення, сакрального світовідчуття та містичного досвіду», вбачає в ньому розв'язання «проблеми віри як феномену індивідуальної й масової свідомості, що виражається в принциповій недовідності тези, яка фіксує істину, яка витлумачується як найвища цінність» [5, с. 33].

Н. О. Боженкова трактує релігійний дискурс у вузькому й широкому сенсах: «У вузькому сенсі релігійний дискурс - це сукупність мовленнєвих актів, використовуваних у релігійній сфері; у широкому набір дій, орієнтованих на залучення людини до віри, а також мовленнєво-мисленнєві комплекси, що супроводжують процес взаємодії комунікантів» [2, с. 17].

Де 6 не протікав релігійний дискурс, одне 3 основних його завдань можна сформулювати таким чином: висловити сподівання, благання, надії вірянина, знайти духовне підживлення, підтримку (або в послідовників тієї ж віри, або у Всевишнього).

Природно, що константою більшості визначень релігійного дискурсу $\epsilon$ концепт віри.

В. І. Карасик, докладно розглядаючи конститутивні ознаки релігійного дискурсу, визначає концепт ВIPА як ментальний стан людини, що 1) розуміє відмінність між даним, повсякденним світом, 3 одного боку, i позамежним, надприродним світом, 3 іншого боку, 2) не сумнівається в існуванні цього позамежного світу, сфокусованого в ідеї центрального створіння - Бога, 3) робить вибір, визнаючи існування Бога, 4) довіряє Богу й чекає від нього допомоги [3, с. 28$].$

Унікальна особливість релігійного дискурсу, за словами В. I. Карасика, полягає в тому, що до числа його учасників належить Бог, 
до якого звернено молитви, псалми, сповіді і який виступає в ролі суперагента [4, с. 321].

Розвиток і форми існування релігійного дискурсу визначаються його цілями: а) отримати підтримку в Бога; б) очистити душу; в) закликати ближніх до віри й покаяння; г) затвердити вірян у вірі й доброчесності; д) через ритуал усвідомити свою приналежність до тієї чи іншої конфесії. Важливу роль у релігійному дискурсі відіграє ритуал. Велика частина вербальних і невербальних дій релігійного дискурсу жорстко ритуалізовані. Якщо спробувати прибрати вербальний компонент із будь-якого іншого типу дискурсу, дискурс просто перестане існувати - чи говоримо ми про політичний, педагогічний, науковий або будь-який інший тип спілкування. «Позбавлення» ж релігійного дискурсу вербального наповнення не припиняє його існування, а лише переводить дане спілкування в дещо іншу іпостась -невербальне (засноване на жестах i рухах) спілкування з Вищим началом - саме тому тільки в релігійному дискурсі виділяється такий жанр, як «невербальна внутрішня молитва».

Як і будь-який інший вид дискурсу, дискурс релігійний оперує своїми власними знаками. Семіотичний простір релігійного дискурсу формується як вербальними, так і невербальними знаками. За ступенем абстракції в межах релігійного дискурсу представляється можливим виділити знаки-копії (або ікони), знаки-символи і знаки-індекси.

Крім зазначених вище типів, у релігійному дискурсі функціонують і численні знаки-артефакти. До артефактів відносять: оздоблення та предмети храму (вівтар, аналой, іконостас), предмети одягу й головні убори священнослужителів (апостольник, мантія, митра, риза, ряса), об’єкти релігійного культу (кадило, хрест, ікона, ладанка, свічка), будівлі та споруди - як види храмових споруд, так і предмети, частини самого храму (амвон, дзвіниця, паперть, ризниця).

Говорячи про знаковий характер релігійного дискурсу, доцільно згадати про функції, які виконує даний вид спілкування. Усі функції релігійного дискурсу можна об'єднати у два великі класи: загальні і часткові, останні з яких, у свою чергу, також неоднорідні і включають ряд підтипів. Серед загальних треба зазначити репрезентативну, комунікативну, апеляційну, експресивну або емотивну, фатичну й інформаційну функції. Усі так звані часткові функції релігійного дискурсу нам представляється можливим об'єднати в три класи: 1) функції, що регулюють базові принципи існування соціуму загалом (функція проспекції / інтроспекції, функція інтерпретації дійсності, функція поширення інформації); 2) функції, що регулюють стосунки між членами даного соціуму (функція релігійної диференціації, функція релігійної орієнтації, функція релігійної солідарності); 3) функції, що регулюють внутрішне світовідчуття, світосприйняття конкретного індивіда, 110 
прескриптивна, прохібітивна, волюнтативна, інспіративна, молитовна, компліментарна функції.

Виділення жанрів у релігійному дискурсі видається дещо складним, що зумовлено: а) складним характером комунікації, оскільки здійснюється спілкування людини з Богом або Бога з людиною, водночас будь-яке висловлювання переростає свої межі і стає подією; б) складним характером іллокутивного потенціалу, сукупності інтенцій, що виявляють досить складні конфігурації.

3 огляду на особливості породження і функціонування релігійного дискурсу, доцільно і прийнятно виділяти первинні і вторинні мовленнєві жанри. До первинних належать мовленнєві жанри притчі, псалма й молитви як індивідуальні типізовані зразки структурно-семантичних i ціннісних моделей, що зародилися в релігійному дискурсі, а вже потім набули широкого функціонування поза релігійного контексту (наприклад, притчі). У розряд вторинних входять мовленнєві жанри, що являють собою своєрідну інтерпретацію й модифікацію первинних релігійних зразків - текстів Святого Письма загалом, що спираються на них композиційно, ситуативно й ціннісно, - проповідb, сповідь. Релігійний дискурс являє собою утворення зі складною жанровою структурою, багатою системою цінностей і концептів, а також рядом специфічних особливостей на мовному рівні.

\section{Література:}

1. Блувберг С. В. Современный протестантский дискурс на материале немецкой ... языке: автореф. дис. ... канд. филол. наук: 10.02.04. Москва, 2009. 27 с.

2. Боженкова Н. А. Некоторые особенности вербального функционирования религиозного дискурса. Известия Юго-Западного государственного университета. Серия «Лингвистика и педагогика». 2015. № 3. С. 15-23.

3. Карасик В. И. Язык социального статуса. Москва, 1991. 495 с.

4. Карасик В.И. Языковой круг: личность, концепты, дискурс. Волгоград, 2002. 477 с.

5. Кожемякин Е. А. Религиозный дискурс: методология исследования. Научные ведомости Белгородского государственного университета. Серия «Философия. Социология. Право». 2011. № 2 (97). T. 15. С. $32-47$.

6. Яскевич О.В. Понятие «религиозный дискурс» в контексте современной теории дискурса: к проблеме определения. Мова і культура. 2012. Вип. 15. Т. 6. С. 5-9. 